\title{
今月の症例
}

\section{胸腺腫に伴った傍腫瘍性非ヘルペス性辺緑系脳炎の32 歳男性例}

\author{
国立国際医療センター神経内科 \\ 久我 敦 上坂義和 國本雅也 \\ 同 呼吸器外科 \\ 長阪 智 \\ 同 第二放射線科 \\ 伊丹 純 \\ 国立精神・神経センター国府台病院神経内科 \\ 岩村晃秀 湯浅龍彦
}

\begin{abstract}
概要 性格変化と記憶障害が爱急性に進行して入院となった.頭部MRI拡散強調像にて海馬に高信号域 を認め, 胸腺腫を合併していた. 䯣液中の単純ヘルペスウイルス抗体価は上昇なく, 抗神経抗体はいず れも陰性であった．腫瘍摘出術を行い，ステロイドパルス療法，放射線照射を行ったところ，術後 36 日目から意識障害が改善した. 胸腺腫に伴った辺縁系脳炎は比較的稀であるが, ときに治療反応性であ り, 集学的治療を試みる価值がある.

〔日内会誌 $94 ： 2385 〜 2387 ， 2005$ ]
\end{abstract}

Key words：傍腫瘍性, 辺縁系脳炎, 胸腺腫

症例

患者：32 歳, 男性. 主訴: 性格変化, 行動異 常, 意識障害. 既往歴・家族歴：特記事項なし. 嗜好歴：機会飲酒，喫煙なし．現病歴：2004 年 4 月末から怒りっぽくなった. 5 月初めから待 ち合わせを何度も確認する，車を停めた場所を 忘れて探し回るなどの行動異常があった. 5 月初 旬の頭部MRIでは異常所見なく，某院からトリ ヘキシフェニジル,ブロマゼパム, ハロペリドー ルを処方されたが, 症状は改善しなかった. 5 月初旬国府台病院精神科を受診したが, 同伴し た家族を外来医師と間違えて挨拶するなどの行 動異常がみられた. 統合失調症を疑われ発症後 12 日目同科に入院となった. しかし病前性格に
問題がなく症状が典型的でないため脳炎等の器 質的疾患が疑われ，同院神経内科に転科した。 5 月入院後 2,3 日目にアシクロビルを投与され たが症状の改善はなく, 入院後 4 日目から免疫 グロブリン $25 \mathrm{~g} /$ 日が 5 日間投与された。同日の 頭部MRI拡散強調像にて右海馬に高信号域を認 めた (図 1)。入院後 5 日目には意識状態がやや 改善したが呼吸促迫となり人工呼吸器管理となっ た.胸部CTから縦隔腫瘍の合併が明らかとなり， 傍腫瘍性辺縁系脳炎の可能性が考えられ, 腫瘍 摘出術および放射線治療を目的として入院後 9 日目当院に転院となった (図 2)。入院時現症： 体温 $38.0^{\circ} \mathrm{C}$, 全身に発汗あり. 意識レベルは薬剤 で鎮静中のため評価困難だが時に自発開眼あり,

〔平成 16 年 10 月 9 日 第 521 回関東地方会推蔗〕

32 year old male case of paraneoplastic non-herpetic limbic encephalitis with thymoma.

Atsushi Kuga ${ }^{1}$, Yoshikazu Uesaka ${ }^{1}$, Masanari Kunimoto ${ }^{1)}$, Satoshi Nagasaka ${ }^{2)}$, Jun Itami ${ }^{3}$, Akihide Iwamura ${ }^{4)}$ and Tatsuhiko Yuasa ${ }^{4)}$ : ${ }^{1)}$ Departments of Neurology, ${ }^{2)}$ Thoracic surgery, ${ }^{3)}$ Radiology, International Medical Center of Japan. Tokyo, ${ }^{4)}$ Department of Neurology, Kohnodai Hospital, National Center of Neurology and Psychiatry, Ichikawa. 


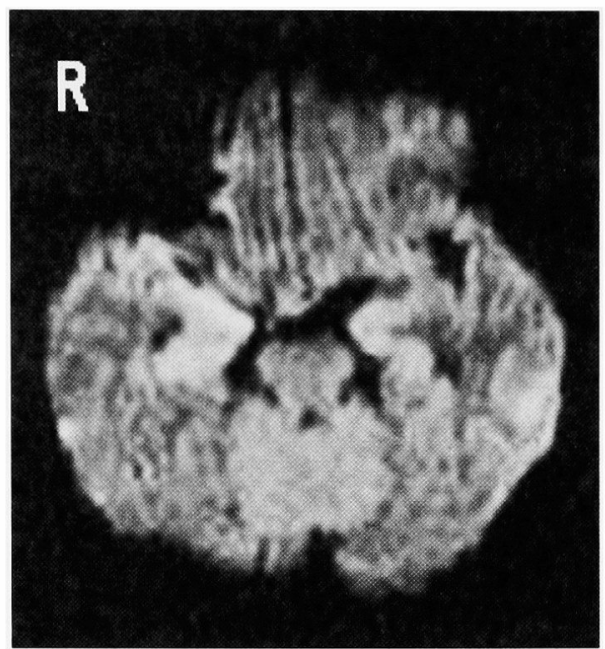

図 1. 頭部MRI（拡散強調画像） 右海馬に高信号域を認めた.

瞳孔に左右差なし，対光反射は両側迅速，睫毛 反射・頭位変換眼球反射なし, 毛様体春䯣反射 両側陽性. 四肢の筋緊張が強く, 痛み刺激で除 皮質肢位をとった。腱反射は左右差なく，Babinski徵候両側陰性, 項部硬直は認めなかった。 入院時検査所見：尿所見，血算，一般生化学に 異常なし. 髄液所見 (入院後 18 日目) 水様透明, 細胞数 $10.9 / \mathrm{mm}^{3}$ (多核 0.3 , 単核 10.6 ), 蛋白 28 $\mathrm{mg} / \mathrm{dl}$, 糖 $82 \mathrm{mg} / \mathrm{dl}$, 細胞診class I, 髄液単純へ ルペス抗体価IgM 10 倍末満IgG 40 倍であった. 脳波所見； $10 \mu \mathrm{V}$ 前後の非常に低振幅脳波で両側 頭頂葉から後頭葉に $\delta$ 波を少量認めた. 発作性異 常波は認めなかった。

臨床経過

入院後 11 日目縦隔腫瘍摘出術を行った. 腫瘍 は胸腺腫（正岡分類IVa，WHO分類B2）であっ た。術後も意識障害が遷延したため, 術後 18 日目から 2 週間でステロイドパルス療法（メチ ルプレドニゾロン $1 \mathrm{~g} /$ 日 $\times 3$ 日)を 2 回行い, さ らに術後 33 日目から放射線治療 (右全胸郭照射 $10 \mathrm{~Gy}$ ，全縦隔照射 40Gy）を行った．術後 36 日目から呼名に開眼するようになり，その後し だいに意識障害，四肢の痤性が改善して，多汗

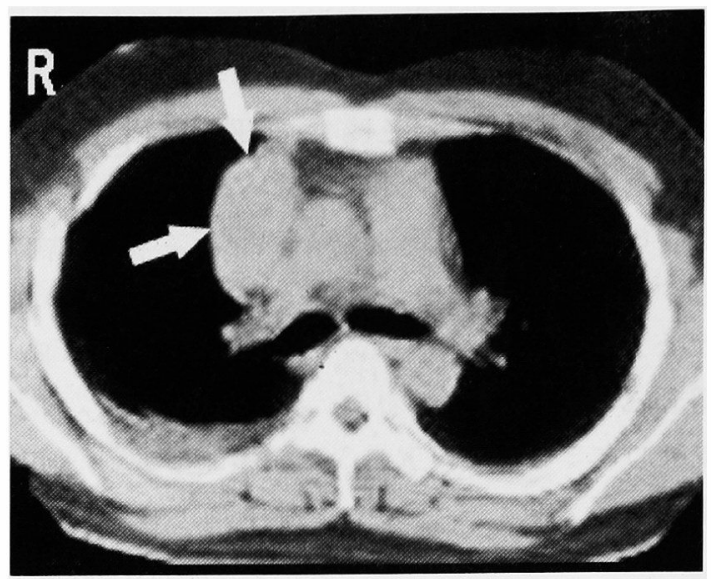

図 2. 胸部CT 前縦隔領域に径 5 センチ×7センチの腫瘤影を認め た.

がみられなくなった．脳波所見の正常化と並行 して高次機能も改善し, 術後 2 力月で長谷川式 簡易痴呆スケールが 22 点となった。 その後も症 状の再燃なく, 2005 年 4 月眼科医として社会復 帰した。

考察

傍腫瘍性辺縁系脳炎 (paraneoplastic limbic encephalitis，以下PLE）の原因としては肺小細 胞癌, 精巣腫瘍が多い. PLE 50 例の解析を行っ た過去の報告では胸腺腫に伴うものは 1 例のみ (2\%)とまれである ${ }^{11}$ 。辺縁系脳炎に共通した症 状として記憶障害, 見当識障害, 性格変化, て んかん発作が多くみられるが，自験例のように 胸腺腫に伴うPLEでは全身の筋けいれん, 多汗を 合併することがある21. 同様の症状をみた場合， 本疾患を念頭におくことは臨床上重要と思われ る.

PLEの病態としては免疫学的機序による腫瘍の 遠隔効果が想定されており, 肺小細胞癌では抗 $\mathrm{Hu}$ 抗体が, 精巣腫瘍では抗Ma2 抗体が疾患特異 的な抗体として同定されている ${ }^{3,4)}$. 胸腺腫に伴 うPLEでは抗VGKC抗体の報告があるが5)，疾患 特異的な抗体は未同定である. 重症筋無力症合 併の報告はいずれも抗アセチルコリンレセプター 
(AchR) 抗体陽性であるが6.7)，抗体価の推移と 辺縁系脳资の病勢は一致していない，本症例も 既知の抗神経抗体と抗AchR抗体は陰性であった. しかし免疫グロブリン投与やステロイドパルス 療法により意識障害が改善したことから, 何ら かの免疫学的機序の関与が考えられる.

治療には腫瘍の摘出, 放射線治療, 化学療法, ステロイド, 免疫抑制薬, 血槳交換と複数の選 択肢があるが，報告によりその組み合わせや順 序は異なるので, 治療指針の確立にはさらなる 症例の蓄積を待つ必要がある。一般にPLEは治療 困難で原疾患によって予後が規定されるが，胸 腺腫に伴った場合は治療反応性のことがあり， 集学的治療を試みる価值が十分にあると考えら れる。

稿を終えるにあたり，抗神経抗体を測定していただいた新 潟大学脳研究所神経内科田中恵子先生に媣謝する。

\section{文献}

1) Gultekin SH. et al: Paraneoplastic limbic encephalitis: neurological symptoms, immunological findings and tumour association in 50 patients. Brain $123: 1481-1494$. 2000.

2) Lee EK, et al : Morvan's fibrillary chorea : a paraneoplastic manifestation of thymoma. J Neurol Neurosurg Psychiatry $65: 857-862,1998$.

3) Graus F, et al: Neuronal antinuclear antibody in sensory neuropathy from lung cancer. Neurology $35: 538-543$. 1985.

4) Voltz R, et al: A serologic marker of paraneoplastic limbic and brain-stem encephalitis in patients with testicular cancer. N Engl J Med 340 : 1788-1795, 1999.

5) Buckley $C$, et al: Potassium channel antibodies in two patients with reversible limbic encephalitis. Ann Neurol $50: 73-78,2001$.

6) Evoli A, et al : Multiple paraneoplastic diseases associated with thymoma. Neuromuscular Disorders 9:601-603. 1999.

7) Fujii $\mathrm{N}$, et al : Limbic encephalitis associated with recurrent thymoma: A postmortem study. Neurology $57: 344^{-}$ 347. 2001. 